\title{
World Views and the Concept of "Traditional"
}

\author{
Raymond Pierotti ${ }^{1^{*}}$ \\ ${ }^{1}$ Department of Ecology and Evolutionary Biology, University of Kansas, Lawrence, USA. \\ pierotti@ku.edu
}

\begin{abstract}
Whether individuals hold static or dynamic worldviews underlies a number of contemporary controversies, including evolution/creationist debates, the reality of climate change, and application of treaty rights by Indigenous cultures. In this last case the debate is often framed in terms of whether or not Indigenous cultures are still using traditional methods when engaged in hunting, fishing, or harvesting. My purpose is to evaluate these issues by arguing that traditional means quite different things in different cultural traditions. In Western cultures, whose roots lie in static worldviews, e.g., those put forth by Aristotle and Descartes, traditional tends to mean unchanged or perhaps timeless. In Indigenous cultures, which typically have dynamic worldviews, traditional (a Western concept), implies that technologies employed, knowledge bases, and even ceremonial practices can change when conditions require. Western thinking assumes that use of the word traditional implies that such concepts or knowledge are of the past and thus unchangeable and irrelevant to the contemporary world. Non-Indigenous investigators have contended that traditional and change are contradictory concepts and that "[traditional] carries the unacknowledged connotation that the item in question is in decline, thus in need of being preserved." In Indigenous thinking, the term traditional implies primarily that such knowledge and its related concepts have been in existence for a lengthy time, precisely because their ability to incorporate new observations and information has kept them fresh and relevant. I discuss these alternative concepts in the contexts of treaty and land rights and contemporary conservation concepts of biodiversity.
\end{abstract}

Received September 3, 2018

OPEN ठACCESS

Accepted October 12, 2018

DOI 10.14237/ebl.9.2.2018.1394

Keywords Traditional, Indigenous beliefs, Western beliefs, World view, Static, Dynamic

Copyright (c) 2018 by the author(s) licensee Society of Ethnobiology. This is an open-access article distributed under the terms of the Creative Commons Attribution-NonCommercial 4.0 International Public License (https://creativecommons.org/licenses/by-nc/4.0), which permits non-commercial use, distribution, and reproduction in any medium, provided the original author and source are credited.

A factor that often goes undiscussed in the examination of contemporary ethnobiological and environmental discussions involving Indigenous peoples is differences in the basic parameters of worldviews, and whether these views are static or dynamic. Static worldviews are largely a creation of Western Civilization, where reliance on a combination of Greek Philosophy from the Socratic tradition with Christian, or at least monotheistic, religious precepts means that it is typically assumed that humans cannot make major changes in how the world functions. The roots of this thinking lie in the ideas of Plato, particularly the concept of Platonic Ideals, which assume that the physical world is an illusion from which little reliable information can be gathered. One conclusion of such thinking was that change and variation were only illusions. The only real things were the ideas or forms, which were considered to be ideal or essential, an idea that lives on in contemporary museum collections with the concept of "type specimens" (Pierotti 2011). Until very recently, all American university graduates were required to take a two-semester series on Western Civilization and its traditions, which firmly implanted the idea of static world views into our most educated citizens. A contemporary, albeit extreme, example can be seen in a discussion of how to deal with the alleged "religion of environmentalism" by a group that calls itself Capitol Ministries, where Drollinger (2018) argues,

To think that man can alter the Earth's ecosystem — when God remains omniscient, omnipresent and omnipotent in the current affairs of mankind - is to more than subtly espouse an ultra-hubristic, secular worldview relative to the supremacy and importance of man. 
Such an argument might be considered humorous, if its precepts did not so clearly underlie the thinking of at least one of the major political parties.

This dichotomy underlies a number of contemporary controversies, including debates over evolutionary versus creationist thinking, the reality of climate change, and application of treaty rights by Indigenous cultures. The first of these is most obvious; Darwinian evolutionary thinking obviously involves change that takes place independent of human actions. Much of the conflict between Western monotheistic religions and evolutionary thinking results from the fact that Western monotheism is very much a static worldview compared with the very dynamic view of the world adhered to by evolutionary biologists. The static nature of pre-Darwinian scientific thought, along with an obvious link to Platonic ideals, can be seen in the "paradigm of 'natural theology' (which) held that God displayed both his existence and his attributes of benevolence and omniscience in the optimal design of organic form and the maximal harmony of local ecosystems" (Gould 2002:338). Gould (2002:338) points out how Darwinian thinking introduced a dynamic worldview in opposition to a static one by refuting 'natural theology' and that:

Evolutionary theory fractured this equation of existence with optimality by introducing the revolutionary idea that all anatomies and interactions [among species] arise as transient products of complex histories, [rather than] as created optimalities (emphasis added).

In the twenty-first century, human caused climate change has risen to rival evolution as a source of controversy between religion and science, basically for the reasons outlined above. Namely this concept of climate change implies clearly that the world can be altered dramatically through the actions of humans, and so if they take such changes seriously, humans might be able to slow or even reverse this process. In contrast, many contemporary climate change deniers no longer deny its existence, but argue that humans are helpless to do anything about it. An example can be seen in the response of a resident of Redding, CA, regarding recent massive wildfires in California, where Wilson (2018) states,

It's "obvious"... "Look at the trees around you right now. The leaves are falling out of the trees when they shouldn't be. The environment is changing, and it's changing everywhere.” But that doesn't mean he thinks it possible to do anything about it. "The good Lord has to fix it. We're not capable of it."

Such thinking may be less scholarly in its wording. However in attitude, it is functionally equivalent to the concepts described above by Drollinger. A more concrete example of a static world view can be seen in the case of Tangier Island, a large sandbar in Chesapeake Bay that is disappearing as a result of sea level rise and resultant erosion. The citizens of Tangier are Christian conservatives, who refuse to accept that climate change is happening and pray that either God or the government will save them, when neither is likely to happen (Swift 2018).

Such critiques and denial of human as the cause of Climate Change illustrate clearly that such attacks are clearly rooted in the norms of a static worldview. As an example, Drollinger (2018) states,

God says He will continually renew the face of the earth until He forms a new heaven and a new earth in the end times (Rev. 21:1). In the thousands of years of climate history since these words were recorded, the veracity of God's promises have (sic) proven to be reliable. So, who then should we trust? It follows that we can all rest assured and wholly rely on God's aforementioned promises per -taining to His ability and willingness to sustain our world's ecosystem.

Most scholars are somewhat familiar with the basic dynamics concerning conflicts of this nature, and may find it surprising that I include controversies over treaty rights invoked by Indigenous peoples as fundamentally similar in structure to these debates among EuroAmericans. My reasoning is that in cases involving treaty rights, it is often argued that, because they have acculturated to some degree with EuroAmerican values and ways of life, that Indigenous peoples are no longer employing traditional methods of hunting, fishing, gathering, and as such their established treaty rights should no longer be applicable. An example I observed personally was the claims that Ojibwe people taking walleye outside of EuroAmerican imposed fishing seasons are not traditional because contemporary Ojibwe fishermen use electric lights instead of torches and fiberglass boats rather than birchbark canoes (see also Nesper 2002). Similar arguments have been made about the Makah Nation's request to be allowed to resume taking gray whales after this species was removed 
from the Federal Endangered Species list (Sullivan 2000). Contemporary Makah drive cars and watch television, therefore EuroAmericans who identify as conservationists contend that they are asking for special privileges not available to other citizens (Sullivan 2000). Arguments often become quite heated over such issues, with death threats being made: environmentalists in Washington State left voice-mail messages consisting of firing a revolver on the answering machines of the Makah tribal council (Sullivan 2000).

To evaluate these issues concerning Indigenous treaty rights it is crucial to recognize that the concept of traditional means quite different things in EuroAmerican and Indigenous cultures, which relates directly to the thoughts and actions of Euromericans' persistent inclination to hold and defend static worldviews even in the new millennium. I (Pierotti 2011:14) have previously written of EuroAmerican attitudes towards Indigenous (native) peoples that,

It seems likely that most people of European ancestry assume that traditional describes only those conditions that existed when a tribe was initially visited and first described by Europeans. This contains the tacit assumption that Indigenous peoples remained essentially unchanged and uninfluenced by any other cultures prior to European contact, (which) is the social equivalent of a creationist perspective.

This is clearly the situation with the attacks on Ojibwe peoples by walleye enthusiasts in Wisconsin and Minnesota (Nesper 2002). In such situations Indian people are apparently assumed to exist in two alternative states: 1) the way they were at first contact by Europeans, and 2) some altered state in which they are either disappearing or have changed to some new state in which they are no longer recognizable as the Indigenous peoples of the Americas. In my experiences with ethnobiologists, I have found that they do not make this mistake, although wildlife and fisheries biologists make such mistakes in a regular manner, along with many EuroAmericans who identify as conservationists.

In Western cultures, whose roots lie in static worldviews, traditional is assumed to mean unchanged or perhaps timeless. Western thinking assumes that use of the word traditional implies that such concepts or knowledge are of the past, unchangeable, and irrelevant to the contemporary world, although there is still a tendency to employ such terminology when referring to traditional family values or to women's traditional roles in society.

One important issue driving this type of worldview is that within Western concepts of reality and their religious traditions, it is always assumed that the ultimate power or goal is external to the earth, i.e., god is to be found in heaven, in "created optimalities" (Gould 2002:338), or humans achieving the kingdom of heaven after living a good life. Another driving force in Western thought is the assumption of progress, which is considered to represent God's will, which is the only acceptable form of change. Human ingenuity is important to driving progress, but this also assumes that humans must exploit nature to progress. Thus, Western thinking assumes that use of the word traditional implies that such concepts or knowledge are of the past and unchangeable, and probably irrelevant to the contemporary world. Most contemporary ethnobiologists have moved well beyond such concepts, although such language can still be found, i.e., the contention that traditional and change are contradictory concepts, and that "[traditional] carries the unacknowledged connotation that the item in question is in decline, thus in need of being preserved" (A. Tanner, personal communications in Pierotti 2011:11).

Traditional is a Western concept, which has been imposed on Indigenous peoples, complete with accompanying baggage. Indigenous cultures tend to regard the way they do things as a "way of life" (Nadasdy 2003:63). Such cultures typically have dynamic worldviews, which allows them to assume that the technology employed, knowledge bases, and even ceremonial practices can change when conditions require (Watson-Verran and Turnbull 1995). In my experience from working with dozens of Indigenous people from a multitude of cultures, rather than assuming that power or ultimate goals are external to the earth, power and goals are considered to come from the earth itself and in living well with the earth and its nonhuman residents. Progress might take place, especially in the form of new technologies. However, the goal of these cultures is not simply to progress, but to persist and survive in the conditions in which they find themselves (Pierotti 2011; Taylor et al. 2005). These traditions did not assume a controlling deity, “...they always have and still do recognize the earth as a living being, as a relative, as 
generative, as sacred..." (Kidwell et al. 2002:54). Indigenous peoples recognize both themselves and other species with which they interact as being, "transient products of complex histories" as described by Gould (2002:338), because they are aware of having shared those "complex histories" with their fellow beings (Pierotti 2011). The absence of a controlling deity, combined with concepts based on long-term relationships with nature and the nonhuman world, allowed these peoples to adjust to changes in the environment, and to assume that humans as part of this world had the ability to alter it or change it on their own terms. Indigenous traditions do not assume progress, but are always ready for change in the environment. If it works in the present it is fine, but the environment is always subject to change; because they are part of that environment, these cultures must also be ready to change as needed (Pierotti 2011).

As a result of their focus on local affairs (Deloria 1992: 114-134), Indigenous cultures are centered on the earth itself and their relationship with it. They can change the earth or respond to its changes through their powerful connections to the earth and the local ecosystem, e.g., through the use of controlled burning (Boyd 1999). If the environment changes they will change with it, while trying as hard as possible to maintain their ways of life. This is actually one method which Indigenous people employ to cope with the European invasion. Many tribes think that if they outlasted the Ice Age, they can outlast European civilization and one of their major goals is to keep Europeans from exterminating their important relatives, i.e., wolves, bears, salmon, bison, deer (see Nadasdy 2003; Pierotti 2011).

As a result, the way in which Indigenous peoples employ the Western concept of traditional (as in Traditional Ecological Knowledge or TEK) is to recognize that such knowledge and its related concepts have been in existence for a lengthy time, precisely because their ability to incorporate new observations and information has kept them fresh and relevant. Not only is individual responsibility paramount in how society is regulated, but individuals can have profound impacts on nature through irresponsible or disrespectful behavior. The Gitxsan and Wet'suwet'en peoples of British Columbia tell a story of how their cultural center was destroyed by landslides after some young men were disrespectful in their treatment of mountain goats (Oreamnos americanus), whom they had been hunting (Glavin 1998). In response, the goats brought down the side of a mountain on the community of Dimlahamid, forcing the people to alter their society. Regardless of whether one accepts the literal truth of this story, the important lesson here is that the culture assumed that behavior by individual members could result in devastating environmental change.

It is important to emphasize at this point that although I characterize the standard Western worldview as being static in nature, I realize this is an oversimplification. In a similar fashion, I also recognize that now that adherence to Christianity has become so commonplace within many Indigenous groups, many Indigenous people have adopted static worldviews through the practice of colonialism and assimilation. Given this state of affairs, there are now, and probably always have been, a number of Europeans and EuroAmericans who through education and knowledge have come to accept and endorse dynamic views of how the world functions. In my experience, this last group consists primarily of scientists, climate scientists, geologists, ecologists, and evolutionary biologists, along with a smattering of other academics and professional scholars. Surprisingly, I have also learned that there are a large number of academics from a wide range of disciplines who continue to adhere to major aspects of static world views. This of course includes the relatively small number of creationist scientists, who can sometimes be found in departments of Molecular Biology or Biochemistry. A more troubling aspect, however, is how static thinking has crept into Conservation Biology and Environmental Science. To many people of European ancestry, conservation means preserving an imagined state of idealized nature, in which no humans have ever set foot. To achieve this goal, conservationists have encouraged the removal of Indigenous peoples from lands where these peoples were probably responsible for the diverse conditions and rich ecosystems that exist (Dowie 2009).

Europeans and EuroAmericans seem to have a perpetual fantasy about the existence of nature untouched by humans (Pierotti 2011). This is a classic example of how a static world view is being applied to one of the most important issues of our time. Chapin (2004:21) said that,

In late 2002, the director of the WWF Latin

America program told me flatly, in reference 
to the Amazon Basin, "We don't work with indigenous people. We don't have the capacity to work with indigenous people...". A CI [(Conservation International)] biologist who works with the Kayapó in the Lower Xingu region of Brazil told me: "Quite frankly, I don't care what the Indians want. We have to work to conserve the biodiversity."

This last comment may sound crass, but it accurately represents the prevalent way of thinking within the large conservation organizations (see Dowie 2009 for detailed examination of this theme).

Although it may seem that this is a fairly esoteric debate at some levels, I contend that it has serious implications for Indigenous peoples, and that we, as ethnobiologists, should work to see that we and our students recognize the harmful impacts of static thinking. At one level, Indigenous dynamic world views are treated as if they were primitive, and it is assumed by people holding static world views that these people have not had any new concepts or discoveries since initial contact with Europeans. As an example, during a presentation at a Symposium on Rethinking The Ecological Indian in 2001 on Indigenous relationships to the natural world, I pointed out some sophisticated ecological and microevolutionary concepts contained within statements made by a Teton Lakota in 1911 (Pierotti 2011:78). Shepherd Krech, author of the controversial book, The Ecological Indian, questioned me about the likelihood that these concepts had been learned through contact with Europeans. My response was to point out that these were relatively modern concepts that had not existed in 1911, when evolutionary thinking was in eclipse, and ecology was not yet a well-developed branch of science. What struck me, however, was that scientific aspects of Indigenous knowledge always had to be attributed to European influences, even at times when Indigenous understanding of ecological principles was much more sophisticated than that of virtually all EuroAmericans. Even today, a significant majority of EuroAmericans reject evolutionary thinking; a significant minority also reject climate change, yet these naïve attitudes are considered mainstream views and discussed seriously in public forums.

In contrast, if Indigenous peoples express sophisticated understanding of relationships among species and wish to re-establish claims over the land they protected and maintained for millennia, it is assumed that they must have learned such thinking from Europeans who had no understanding of such concepts, and most of whom still lack such understanding. If Indigenous people wish to resume hunting and fishing rights concerning species that they managed carefully, they are told that they are no longer real or true Indians if they choose to employ modern technologies that increase their efficiency and reduce suffering of their prey. In addition, their lives, and even their cultures, are threatened by people who think they are protecting biodiversity, when it is the dominant culture whose actions threaten this biodiversity, and many conservationists assume that Indigenous people are equivalent in their thinking to their own greed-driven culture.

\section{Declarations}

Permissions: None declared.

Sources of Funding: None declared.

Conflicts of Interest. None declared.

\section{References Cited}

Boyd, R., ed. 1999. Indians, Fire, and the Land in the Pacific Northwest. Oregon State University Press, Corvallis, OR.

Deloria, V. 1992. God is Red. North American Press, Golden, CO.

Chapin, M. 2004. A Challenge to Conservationists. World Watch Magazine 17:17-31.

Dowie, M. 2009. Conservation Refugees: The Hundred Year Conflict Between Global Conservation and Indigenous Peoples. MIT Press, Boston.

Drollinger, R. 2018. The Bible and Policy [web page]. Capitol Ministries. Available at: https://capmin.org/ coming-to-grips-with-the-religion-ofenvironmentalism/. Accessed on August 15, 2018.

Glavin, T. 1998. A Death Feast in Dimlahamid. New Star Books, Vancouver.

Gould, S. J. 2002. I have Landed: The End of a Beginning in Natural History. Harmony Books, New York.

Kidwell, C. S., H. Noley, and G. E. Tinker. 2002. A Native American Theology. Orbis Books, Maryknoll, NY.

Nadasdy, P. 2003. Hunters and Bureaucrats: Power, Knowledge, and Aboriginal State Relations in the Southwest Yukon. UBC Press, Vancouver.

Nesper, L. 2002. The Walleye War: The Struggle for Ojibwe Spearfishing and Treaty Rights. University of Nebraska 
Press, Lincoln, NE.

Pierotti, R. 2011. Indigenous Knowledge, Ecology and Evolutionary Biology. Routledge, Taylor and Francis Group, New York and London.

Sullivan, R. 2000. A Whale Hunt: Two years on the Olympic Peninsula with the Makah and Their Canoe. Scribner Press, New York.

Swift, E. 2018. Chesapeake Requiem: A Year with the $W$ atermen of $V$ anishing Tangier Island. Harper Collins Publishing, New York.

Taylor, L., G. K. Ward, G. Henderson, R. Davis, and L. A. Wallis. 2005. The Power of Knowledge, The Resonance of Tradition. Aboriginal Studies Press,
Canberra, Australia.

Watson-Verran, H., and D. Turnbull. 1995. Science and Other Indigenous Knowledge Systems. In Handbook of Science and Technology Studies, edited by S. Jasanoff, G. E. Markle, J. C. Peterson, and T. Pinch, pp. 115-139. SAGE Publications, Thousand Oaks, CA.

Wilson, J. 2018 Surrounded by Fire, California Politicians Question Links to Climate Change [web page]. The Guardian. Available at: https:// www.theguardian.com/environment/2018/ jul/31/california-wildfire-climate-change-carr-fire. Accessed on August 16, 2018. 